\title{
Assessing the Effects of Privatization on State Enterprises in Ghana
}

\author{
Isaac Akomea-Frimpong $^{1^{*}} \quad$ Modjinou Yaovi Sebia ${ }^{2} \quad$ Temitayo. O. Olaniyan ${ }^{3}$ \\ 1. Department of Finance, University of Ghana, P. O. Box LG 25, Legon, Ghana \\ 2. Daqing Dongfeng High School, Saertu District, Daqing City, China \\ 3. Department of Finance, University of Ilorin, Ilorin, Nigeria
}

\begin{abstract}
This paper examines the effects of privatization on state enterprises in Ghana. Vodafone Ghana and Universal Merchant Bank were selected for this study. Primary data was obtained from 287 respondents through survey questionnaires together with secondary data from the published annual financial reports of the two companies. The results of the study showed that factors such as weak internal controls, bribery and corruption, mismanagement of resources, political interference for self-reasons, and increased debts influence the privatization of state enterprises. The results also showed that non-financial effects of privatization include the improved efficiency in delivering services to consumers. Financially, privatization leads to significant improvement in profits, liquidity, solvency and investments stance of state enterprises. It is recommended that there must be a well-drafted strategic policy to manage the privatization of state enterprises in respective of the government in power. Capacity building through training must be offered to employees of state enterprises to revolutionise the innovative abilities and outputs. Effective internal controls must be institutionalize to bolster the operational efficiency of state enterprises.
\end{abstract}

Keywords: Factors, Financial Ratio, Performance, Privatization, State Enterprise

DOI: $10.7176 /$ RJFA/10-8-14

Publication date: April $30^{\text {th }} 2019$

\section{Introduction}

Privatization in developing countries emerged as a policy issue amidst the debt crises and worsening fiscal budget performances in the seventies and the early eighties (Nwoye, 2011; Oppong, 2013). Since then privatization has been promoted in most countries as part of economic reform strategies, and as a condition for financial assistance from the World Bank and IMF (Konadu-Agyemang, 2018). In Sub-Saharan Africa (SSA), in particular, the privatization and reform of state enterprises (SEs) have occupied a central position on the adjustment agenda since the late 1990s, because SEs despite attempts at reform, had presented a depressing picture of inefficiency, losses, budgetary burdens, poor products and services, and minimal accomplishment of their non-commercial objectives (Gogo, 2011). Privatization occurs when there is a transfer of productive operations and assets from the public sector to the private sector, it is much more than selling an enterprise or corporation to the highest bidder (Bauer, 2015). According to the guidelines given by the World Bank and the IMF, privatization is only deemed to have occurred when the government reduced its shareholding in the corporation to 25\% or less (World Bank, 2015). Large scale privatization started in the 1960s when the Federal Republic of Germany sold a majority stake in Volkswagen in a public issue heavily tilted towards small investors (Raco, 2016). There are a number of ways to privatize state-owned corporations which includes sale of shares where the government will sell off its shares through methods like competitive sale, public floatation and pre-emptive rights, sale of assets using ways like open tenders, public auction, direct sale and liquidation of assets, management buyouts and employee buyouts, transfer of assets and shares, equity dilutions, joint ventures, restitutions and management contracts (Adeyemo \& Salami, 2008).

Deteriorating conditions of the state sponsored enterprises paved the way for the design and implementation of extensive privatization program from 1981 under the Structural Adjustment Program (SAP) undertaken by the Provisional National Defence Council (Conteh \& Ohemeng, 2009). Reasons cited for this privatization program through SAP include overwhelming corruption scandals, mismanagement of funds, political interferences and lack of innovation in the state enterprises. A cursory look at studies like Konadu-Agyemang (2018) and Oppong (2013), Tsamenyi, Onumah and Tetteh-Kumah (2010) few studies have sought to assess the impacts of privatization on state enterprises in Ghana. The transition from state-owned to private enterprise is a dramatic change. The takeover of government assets or services by the private sector poses a magnanimous impact on the masses, thus, the factors that drive this takeover must be known and managed properly. The central aim of this study is to analyze the impacts of privatization on the performance of SEs. Specific objectives of this paper include i) the determination of factors that affect privatization of state enterprises in Ghana; and ii) the analysis of the effects of privatization on state enterprises in Ghana. Other sections of the paper cover the literature review which presents a review of preliminary studies on privatization of state enterprises. The next section after this shows the research method. It is followed by data analysis, and the paper ends with conclusions and recommendations. 


\section{Literature Review \\ 2.1 State Enterprises}

Nolan and Xiaoqiang (1999) noted that state enterprises can be defined based on the author's own view or philosophical leanings. For some people, State enterprises (SEs) can be government entities run for providing public goods and service, while others claim they are government entities for profitmaking objectives (Megginson, 2017). SEs can also be defined as an enterprise whose capital is wholly or for the major part-owned by the state through direct placement originating from reserved state assets (Zeng, 2013). The influence of state ownership presents a different perspective on the SE's objectives. The provision of public utilities and national economic development are the dominant factors underlying the government's decision to establish SEs, which later becomes the driving factor for the government to set up socio-political objectives for SEs (Millward, 2013). In traditional views, SE objectives engage with the requirement to meet government social welfare maximizing objectives (Hanschen \& Erspamer 2004). SEs are also encouraged to reconcile with the government's socio-political objectives. SEs also have to carry certain non-economic objectives, which still relate to industrialisation or national economic development, such as employment, state budget or public utility facilities (Hayllar \& Wettenhall, 2013). In addition to their social welfare objectives, SEs have financial objectives. These have mostly developed since the SE is considered as a business entity. The development of financial objectives is mostly influenced by private entities whose run in the same business area. In a general context, financial objectives can be defined as both direct and indirect, with implications for cost (Chen, 2017); while for general business entities, financial objectives commonly engage with profit. For business entities, profit-seeking, or maximizing profit, is a natural economic or financial objective (Harris, 2013). In fact, there is a difference between 'profits', an excess of revenue over cost, and 'profitable', as a measure of return on resources which is not clearly stated as part of the SEs' objectives.

The government's objectives for SOEs often engage with the government's roles and the state's needs. The government is the only authorized body within society; thus, its activities will have collective effects (Mains, 2012). Besides social welfare duties, the government's roles include facilitating national economic growth, providing public facilities and improving market activities when private participants are limited. The development of the national economy and other parties' participants in national economic activities contributes to the intensity of the government's involvement in these activities. Competition may place pressure on SEs and private entities to be profitable and efficient. In practice, SEs' managers may deal with other parties who are part of the stakeholder group, such as employees, the government and communities (Weiss, 2014). These stakeholder groups may also determine the basic needs and end the result of SEs' business. Profits, efficiency and good-quality goods and services are the public and government's major critiques for SEs. The public and the government often require SOEs to be more profitable and efficient, like private entities. As stockholder and stakeholder for SOEs, the government's influence is not limited to determining the objectives. The government regulates the market where SEs and private participants run their businesses (Millward, 2013). The regulation often requires SEs to fairly compete with private entities, and they are also obligated not to disadvantage private participants in the market. SEs have to balance their market activities as businesses and public entities.

\subsection{Privatization}

Privatization is a global phenomenon with much emphasis or transactions happening in developing countries. Countries that have announced their intention of launching some kind of privatization program allow for the possibility of private ownership of the means of production and for the operation of markets as an essential feature of the economy's functioning (Weiss, 2014, Raco, 2016). Sometimes privatization is construed very narrowly to mean just the sale and legal transfer of the ownership of public enterprises to private entrepreneurs, and sometimes more broadly to include the legal transfer of just the control of public enterprises and services but not outright ownership (Kerlin, 2012). Amoako and Goh (2015) considered privatization as the transfer of assets from the public sector to the private sector, from the domain of public ordering to that of private ordering, which appears to fit more into the narrower view of the term. Starr (1988) defined the term as: (1) Any shift of activities or functions from the state to the private sector; and more specifically, (2) any shift of the production of goods and services from public to private which would fit more into the broader view of the term. The shifting of a function, either in whole or in part, from the public sector to the private sector is privatization. World Bank has defined privatization as a transaction or transactions utilizing one or more of the methods resulting in either the sale to private parties of a controlling interest in the share capital of a public enterprise or of a substantial part of its assets or the transfer to private parties of operational control of a public enterprise or a substantial part of its assets (Bonin, Hasan \& Wachtel, 2005). Appiah-Kubi (2001) posited that privatization refers to all initiatives designed to increase the role of private entities for applying society resources to produce products and services by decreasing and restricting government or official's roles. Ginsburg (2005) saw privatization as being the creation of freedom from direct state control and the transfer of business undertakings to private hands. 


\subsection{Recent Studies on Privatization of State Enterprises}

Appiah-Kubi (2001) stated that between 1987 and 1999, Ghana's privatization programme generated revenues for the government equivalent to about $14 \%$ of GDP from a moribund public sector which had previously been dependent on state subventions, and thus succeeded in fulfilling a key role in easing the fiscal crisis and in fostering the Structural Adjustment Programme. The big question remained in the 1990s, whether the privatization process would help the growth of Ghana's economy and help maximize political gains. His article reviewed the experience of Ghana in privatizing public enterprises and assessing the impacts of the ongoing privatization programme on the Ghanaian economy in the early 2000s. It suggested that, in spite of the high proceeds, the net direct revenues from privatization was relatively modest, due to the high outstanding credit sales, the high costs of divestiture and high outstanding liabilities of privatized firms. It also appeared from his studies that the programme placed too much emphasis on public finance rationalization and faith in the market system, and too little on socio-political and regulatory issues. Equally, the inadequate attention given to post-privatization regulation of privatized businesses, and the use of the divestiture programme as a political patronage instrument to reward the regime's friends and political insiders conferred limited success for privatization in achieving its goal of enhancing efficiency, private sector investment, and employment.

Tsamenyi, Onumah and Tetteh-Kumah (2010) were of the view that a significant number of less developed countries (LDCs), including Ghana, have embraced the World Bank/IMF led economic reforms. Ghana has been implementing these reforms since early 1980. One of the conditions of the reforms is the privatization of former state-owned enterprises (SOEs). Such privatization activities have however generated debates among academics, practitioners, and policymakers. The stated that research findings before their study were mixed. Their study analyzed the performance of two large privatized companies in Ghana. Both companies have been paraded by the Ghanaian authorities and the international financial community as success stories of privatization. Their objective was to examine how and why these firms have been claimed to be successful. Drawing on the dimensions of the balanced scorecard, they examined the performance of the firms from five main perspectives- financial, customers, internal business process, learning and growth, and the community. The analysis was based on data gathered from diverse sources, namely, semi-structured interviews and discussions with managers of the selected companies and with personnel from key government departments, and analysis of internal and external documents. They concluded that overall the performance of both organizations improved after privatization under all the performance dimensions examined. These improvements were also accompanied by certain organizational changes, including changes in the accounting and control systems. However, they did not claim that all privatization programs in Ghana have been successful. The study recommended that future studies should adopt multidimensional approaches to assess the phenomenon.

Omran (2015) conducted a study on the Egyptian economy and evaluated the financial as well as the operating performance of newly privatized Egyptian state-owned enterprises and determines whether such performance differs across firms according to their new ownership structure. The Egyptian privatization program provided unique post-privatization data on different ownership structures. Since most studies did not distinguish between the types of ownership, this paper provided new insight into the impact that post-privatization ownership structure has on firm performance. The study covered 69 firms, which were privatized between 1994 and 1998. For these newly privatized firms, this study documented significant increases in profitability, operating efficiency, capital expenditures, and dividends. Conversely, significant decreases in employment, leverage, and risk are found, although output showed an insignificant decrease following privatization.

Mutugi and Ngugi (2013) researched into the relationship between privatization and performance of firms listed on the Nairobi Security Exchange. The target population was public corporations that were privatized and listed on the Nairobi Security Exchange. Secondary data from the financial statements of the listed firms together with questionnaires were used for this study. Descriptive statistics such as percentages, frequency tables, graphs, and regression analysis were used to analyse the data. The study found that the institution of board of directors was best to manage privatized firms. The study also found a significant influence of privatization on the performance of listed firms.

Arocena and Oliveros (2012) compared the pre- and post-privatization efficiency of a sample of state-owned enterprises privatized in Spain with the efficiency of their closest private competitors. They performed a two-stage double bootstrap data envelopment analysis model. In the first stage, the efficiency was estimated through a bootstrapped data envelopment analysis, and then followed in the second stage by a bootstrapped truncated regression. Their results provided evidence that (i) there were no significant differences in efficiency between the state-owned enterprises and their private counterparts before privatization; and (ii) the efficiency of newly privatized firms significantly increased after their privatization, while private competitors showed no significant improvement during the same post-privatization period.

\section{Research Method}

The quantitative research design underpinned the analysis of the issues in this study with two state enterprises 
which were sold to private companies. Quantitative research approach was chosen because it emphasizes the objective of measurements, statistical and numerical analysis of data collected through questionnaires and annual financial reports of the companies used in this study (McCusker \& Gunaydin, 2015). Creswell and Clark (2017) stated that quantitative approach has the capacity to offer an objective perspective of a phenomenon being studied. The population for this study comprised two state enterprises which were sold by the Government of Ghana. These companies have over 1000 employees ranging from managers to operatives. These companies were selected because they have a large customer base in Ghana, and they form part of the fundamental pillars of the socioeconomic development of the country in areas of telecommunication and financial service (these companies are Universal Merchant Bank Limited and Vodafone Ghana Limited). 287 respondents accepted to be part of this study by filling and returning the survey questionnaires. These respondents are those in the middle and top management level of the two companies. Questionnaires were designed and checked by experts on state enterprises before a pilot test. The elements contained in the questionnaire were modified after it was examined by the experts and the pilot testing. A Cronbach Alpha was run to know the extent of the reliability of the key issues in the questionnaire, and the results proofed that the elements were acceptable for study with a Cronbach Alpha greater than 0.5 . In addition, secondary data was obtained from these companies collected and analysed to examine the financial performance of the two companies before and after the privatization. In order to achieve the objectives of this study, financial ratios were sued to examine the performance of the two companies before and after the privatization. Descriptive statistics of means, percentages and standard deviations analysed the Likert Scale of factors influencing privatization of state enterprises.

\section{Data Analysis}

4.1 Background information of Respondents

Table 1. Demographic characteristics of respondents

\begin{tabular}{lcc}
\hline Demographic Variables & Frequency & Percentage $\%$ \\
\hline Job Title: & & 28 \\
Top Managers & 207 & 72 \\
Line Managers & & 80 \\
Level of Education: & 230 & 20 \\
Degree/tertiary & 57 & 55 \\
Postgraduate/masters & & 25 \\
Wess than 10 years & 158 & 20 \\
11-20 & 72 & 57 \\
\hline
\end{tabular}

From Table 1, it can be inferred that $80 \%$ of those who responded to the questionnaires possessed undergraduate degree qualifications and $20 \%$ of the respondents have postgraduate degrees, and some of these respondents (be it undergraduate degree or masters) has certificates from professional bodies like public management, business analysis, accountancy, finance, and others. Postgraduate holders are participants who have furthered their education either in Ghana or abroad. The level of education of a person is always a key determinant of the person's contribution to an important discussion (Onsomu, Kaijage, Aduda \& Iraya, 2017) but this finding has been disputed by Abbas and Raja (2015). The job title section showed that $28 \%$ of the respondents are top managers. These respondents are in charge of the management of the state enterprises on a daily basis. They represent enterprises from time to time in State Enterprise Commission (SEC) meetings. SEC is the umbrella body for the management of all the state enterprises in Ghana. And the managers (directors) of the companies are in charge of negotiating the deals on the privatization of the enterprises. They prepare and send reports to the Board of Directors of the various companies and to SEC on the issues and performance of the company. They make sure the targets of the various companies they supervise and manage are met and they are held responsible in case their funds are misappropriated. The results also show that $72 \%$ of the respondents are line managers of the privatized enterprises in this study.

The respondents were quizzed on how long they have been in contact with companies to ascertain their level of understanding of the various issues that are related to privatization as well as their understanding of the reports prepared and issued by the state enterprises. Table 1 also showed that, $20 \%$ of the respondents who have worked for less than five years; $55 \%$ of the respondents have known their companies for less than 10 years, $25 \%$ of the respondents have an idea about privatization of state-owned enterprises and policies attached to them for 11 to 20 years and $20 \%$ of the respondents both the managers and the employees have experience from their companies for more than 20 years.

\subsection{Factors influencing Privatization of State Enterprises}

Table 2 presents the factors influencing the sale of state enterprises by successive governments after the overthrow 
of the first republic in Ghana in 1966. From internal management perspective, weak internal controls with bureaucratic systems which lead to corruption and unproductivity account for privatization. A ruling government will be triggered to sell a state enterprise if that enterprise is reporting high level of unproductivity (Appiah-Kubi, 2001). The poor conditions of internal systems of state enterprises give policymakers the impetus to sell the enterprise (Zhou, Gao \& Zhao, 2017).

Private companies and firms have a greater incentive to produce goods and services more efficiently to increase profits. A private business has the ability to focus all relevant human and financial resources onto specific functions. State-owned firm do not have the necessary resources to specialize its goods and services as a result of the general products provided to the greatest number of people in the population. Conversely, the government may put off improvements due to political sensitivity and special interests even in cases of companies that are run well and better serve their customers' needs. A state-monopolized function is prone to corruption; decisions are made primarily for political reasons, personal gain of the decision-maker (i.e. "graft"), rather than economic ones. Corruption (or principal-agent issues) in a state-run corporation affects the ongoing asset stream and company performance, whereas any corruption that may occur during the privatization process is a one-time event and does not affect ongoing cash flow or performance of the company (Harris, 2013). Then again, managers of privately owned companies are accountable to their owners/shareholders and to the consumer, and can only exist and thrive where needs are met but this absent in the state enterprises in many occasions. Managers of publicly owned companies are required to be more accountable to the broader community and to political "stakeholders" which leads to a lot of conflicts on roles and interests and it burdens their scope of operations (Gago, 2011). This reduces their ability to directly and specifically serve the needs of their customers.

A political government tends to run state enterprises and their industries for political goals rather than economic ones. This exhibit crass incompetence and mismanagement of resources. Due to this state enterprises become cash strapped. Privately held companies can sometimes more easily raise investment capital in the financial markets when such local markets exist and are suitably liquid than state enterprises, thus, the need to sell it to a private investor. State-owned industries have to compete with demands from other government departments and special interests for finance to support their projects. Governments have had the tendency to "bail out" poorly run businesses, often due to the sensitivity of job losses, when economically, it may be better to let the business fold as was seen after the 2007-2008 financial crisis in the advanced world (Weiss, 2014; Zeng, 2013). This is when the companies are experiencing huge operational loses and the company is becoming insolvent. The constant losses in the operations of the financial reports push the governments to sell the companies.

Poorly managed state companies are insulated from the same discipline as private companies, which could go bankrupt, have their management removed, or be taken over by competitors (Nwoye, 2011). Private companies are also able to take greater risks and then seek bankruptcy protection against creditors if those risks turn sour. Natural monopolies. The existence of natural monopolies does not mean that these sectors must be state-owned. Governments can enact or are armed with anti-trust legislation and bodies to deal with anti-competitive behaviour of all companies public or private. Ownership of and profits from successful enterprises tend to be dispersed and diversified over time especially if the companies are not innovative and they don't adapt to technological changes (Chen, 2017). The availability of more investment vehicles stimulates capital markets and promotes liquidity and job creation. State enterprises and nationalised industries are prone to interference from politicians for political or populist reasons. Examples include making an industry buy supplies from local producers (when that may be more expensive than buying from abroad), forcing an industry to freeze its prices/fares to satisfy the electorate or control inflation, increasing its staffing to reduce unemployment, or moving its operations to marginal constituencies. Over the years, these interferences have not helped the cause of the helped the state enterprises to do well. In order to wean their hands off from the affairs of the state enterprises, they offload their shares in these firms and give it to the private investors to manage the enterprises (Conteh \& Ohemeng, 2017).

Corporations exist to generate profits for their shareholders (Raco, 2011, Omran, 2007). Private companies make a profit by enticing consumers to buy their products in preference to their competitors' (or by increasing primary demand for their products, or by reducing costs). But on many occasions, customers accuse state enterprises of providing them with poor services with poor attitudinal behaviour from the employees. The employees are not managed properly, they exhibit lackadaisical attitudes to work, and lateness and absenteeism are their hallmarks. The employees also push the blame on the poor conditions of services given to them by their organisations with no allowances, poor pension packages, and low wages. Competition from foreign imported goods and organisations bring to the abrupt end the monopolisation and the profits enjoyed by the state enterprises, and this is worsened by the unfavourable macroeconomic factors on inflation, interest rates, and exchange rates which affect state enterprises negatively. 
Table 2: Factors influencing privatization of state enterprises in Ghana

\begin{tabular}{lcc}
\hline Factors that lead to privatization of state enterprises & Mean & Std. Dev \\
\hline Weak internal controls and systems & 4.32 & 2.11 \\
Mismanagement of resources & 4.21 & 2.05 \\
Rampant occurrence of fraudulent activities & 4.43 & 2.23 \\
Nepotism, bribery and corruption & 4.53 & 2.29 \\
Huge debt and a large number of creditors & 4.71 & 2.34 \\
Poor management style & 4.56 & 2.29 \\
Poor attitudes towards work by employees: laziness, lateness to work, loitering & 4.83 & 2.42 \\
around, gambling and the excessive use of social media & 3.87 & 2.45 \\
Poor employee welfare on holidays, maternity, pensions and allowances & 4.89 & 2.48 \\
Poor services and products to consumers & 3.45 & 2.11 \\
Unhealthy competition from imported products and foreign firms & 3.91 & 2.46 \\
High government interference & 4.84 & 2.42 \\
Unfavorable macroeconomic conditions &
\end{tabular}

\subsection{Effects of Privatization on State Enterprises}

\subsubsection{Non-financial effects of Privatization}

It can be observed from Table 3 that the non-financial impacts of privatization include improved services to consumers. The privatization of Ghana Telecom (now Vodafone Ghana) and Merchant Bank (now Universal Merchant Bank) have brought more comfort and diverse products and quality services to the consumers who subscribe to these companies. These companies have become more competitive and they have taken measures to reduce the inefficiencies which existed previously. Privatised firms are innovative and entrepreneurially active. Politically, the influence over the decision making and activities of the two companies has reduced and it is now run by directors who are accountable to their shareholders with little influence of the government.

Table 3: Non-financial impacts of privatization of state enterprises

\begin{tabular}{lcc}
\hline Non-financial impacts of privatization & Mean & Std. Dev. \\
\hline Improved quality services to consumers & 4.87 & 2.42 \\
Improved competition and efficiency & 4.63 & 2.43 \\
Improved innovation and entrepreneurship & 3.98 & 2.41 \\
Reduced political interference or influence & 3.73 & 2.38 \\
\hline
\end{tabular}

\subsubsection{Financial effects of Privatization}

The financial ratios analysis below are used to evaluate and assess the performance of Vodafone Ghana Limited and Universal Merchant Bank based on five-year averages before and after the privatization of the two companies. a) Profitability Analysis

Gross Profit Margin

Figure 1: Gross Profit Margin

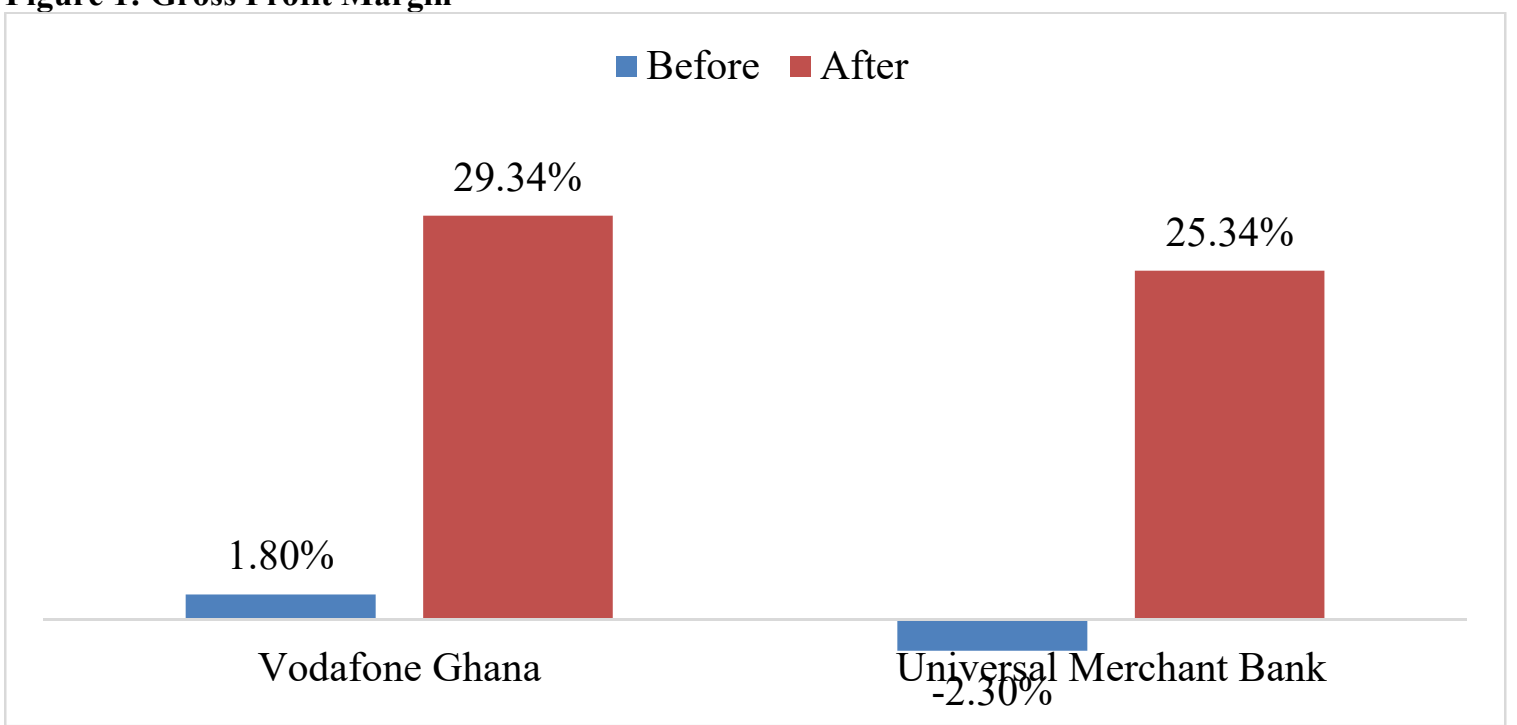

Gross profit margin is a financial metric used to assess a company's financial health and business model by revealing the proportion of money left over from revenues after accounting for the cost of services (Edwards, 2016; Omran, 2007). Gross profit margin, also known as gross margin, is calculated by dividing gross profit by revenues. 
Vodafone Ghana had a five-year average gross profit margin of $1.8 \%$ before it was privatized but this figure changed after to $29.34 \%$ after it was sold to private investors. Compared to Universal Merchant Bank, the bank had a 3 -year average gross of $-2.3 \%$ before the bank was acquired by Fortis, a private equity fund in 2013 but this changed to $25.34 \%$ after the privatization. The increase can be attributed to the huge privatization where the operating costs of these companies were cut down.

Net profit Margin

Net profit margin is the percentage of revenue left after all expenses have been deducted from total income (Tian $\&$ Estrin, 2008). The measurement reveals the amount of profit that a business can extract after all the expenses of the firms have been deduced. The net profit margin of Vodafone Ghana before the company was acquired was profit margin was $-12.34 \%$ but this figure changed since the company was acquired to $14.23 \%$ (see Figure 2). The performance of Universal Merchant Bank of Ghana was poor before it was acquired $(-14.11 \%)$ of net profit margin but it has since changed for better after the company was privatized (12.53\%). The increase in the net profit margin of these companies after they were privatized could be attributed to reduction in higher interest expense from the long term debt they acquired to finance their businesses and the realisation from the synergies that come with the privatization. All the administrative expenses of the two companies saw a decline after they were privatized.

\section{Figure 2: Net Profit Margin}

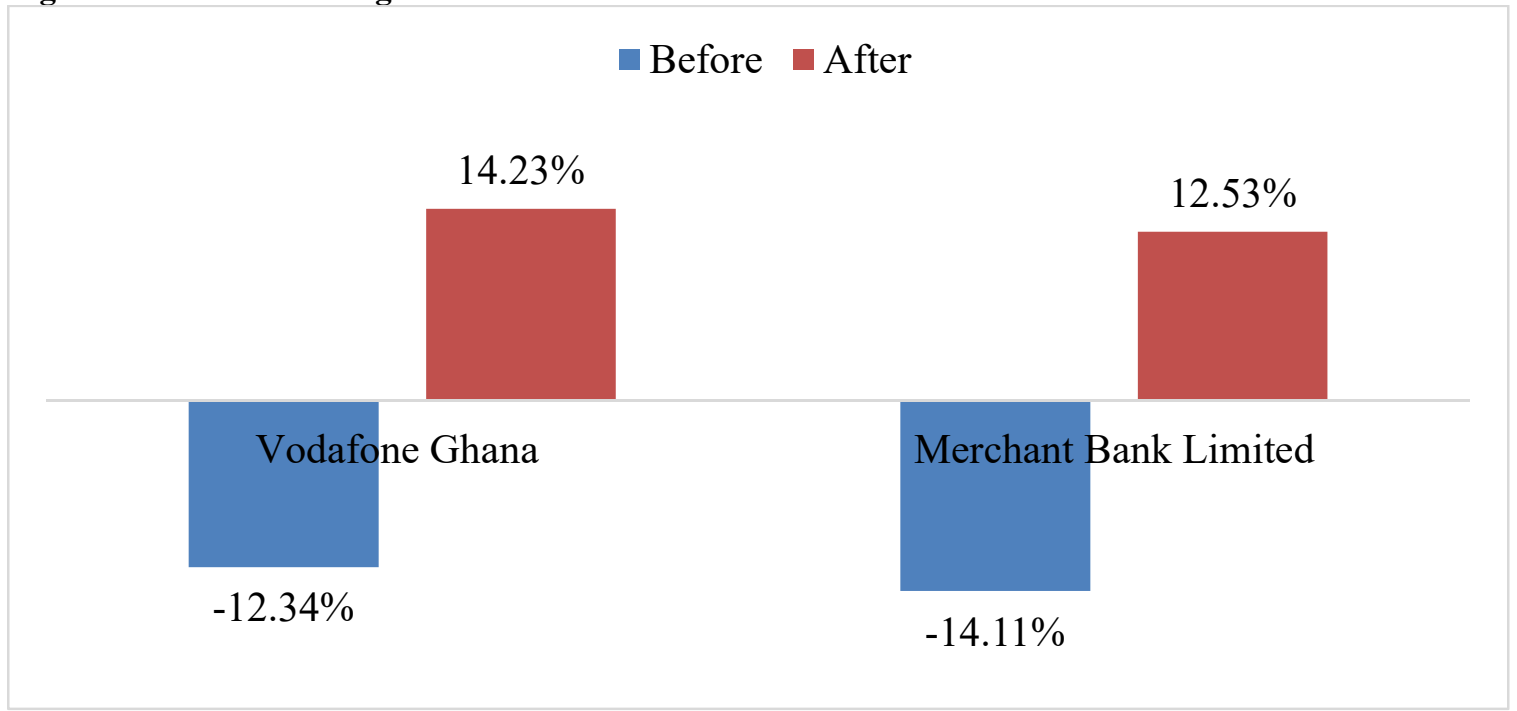

\section{Return on Investment}

Figure 3: Return on investment (ROI)

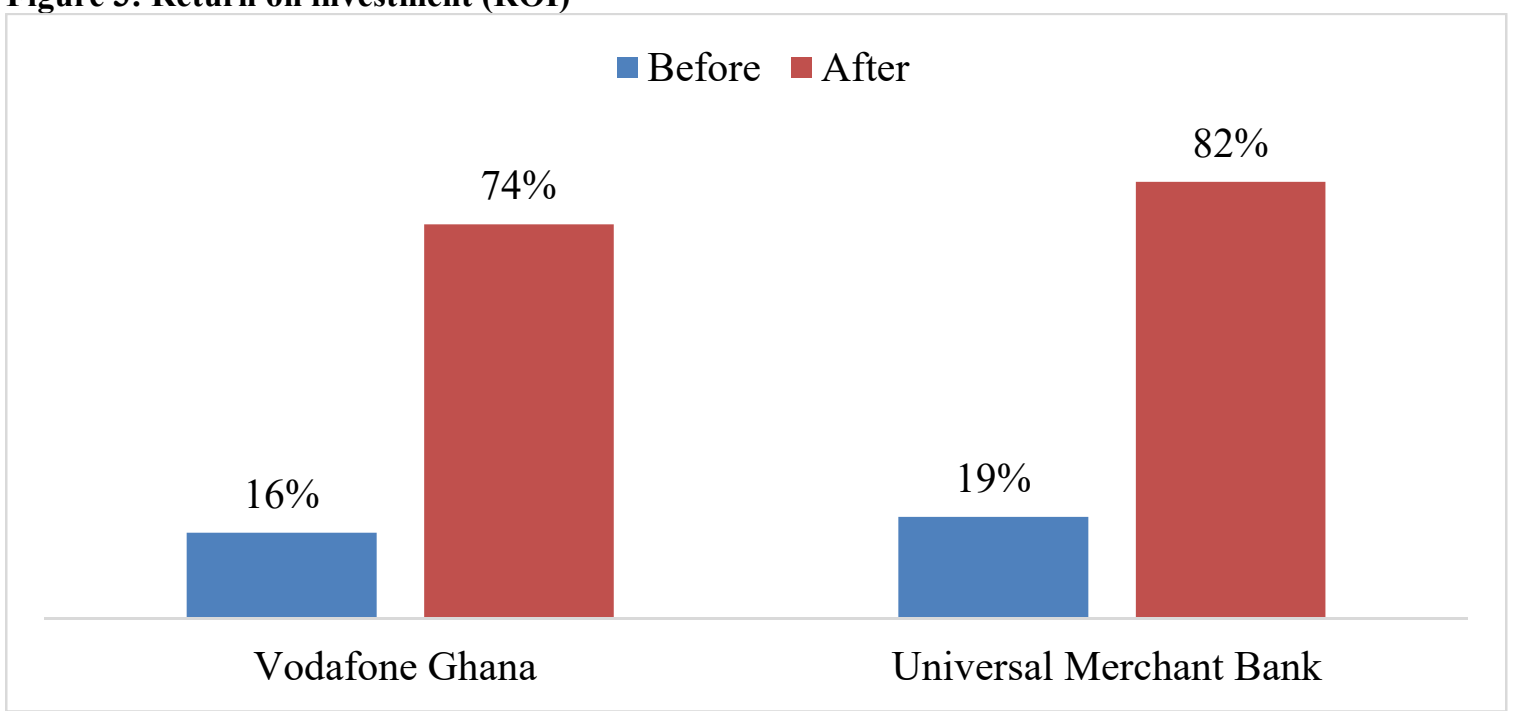

From Figure 3, the Return on investment which is an effective profitability indicator shows ROI for Vodafone Ghana before the privatization was $16 \%$, increasing to $74 \%$ after the privatization compared to Universal Merchant Bank that experienced $19 \%$ and then it increased to $82 \%$. The $300 \%$ growth in the total asset after the acquisition mostly came from intangibles like brands and goodwill which do not generate much profit. This could also be as a result of huge income tax reduction to these firms which may be the economic and political decision by the 
government to help the privatized firms to flourish.

b) Liquidity Position Analysis

The short-term finance stance of the two companies were assessed by current ratio.

Figure 4: Current ratio of the before and after privatization

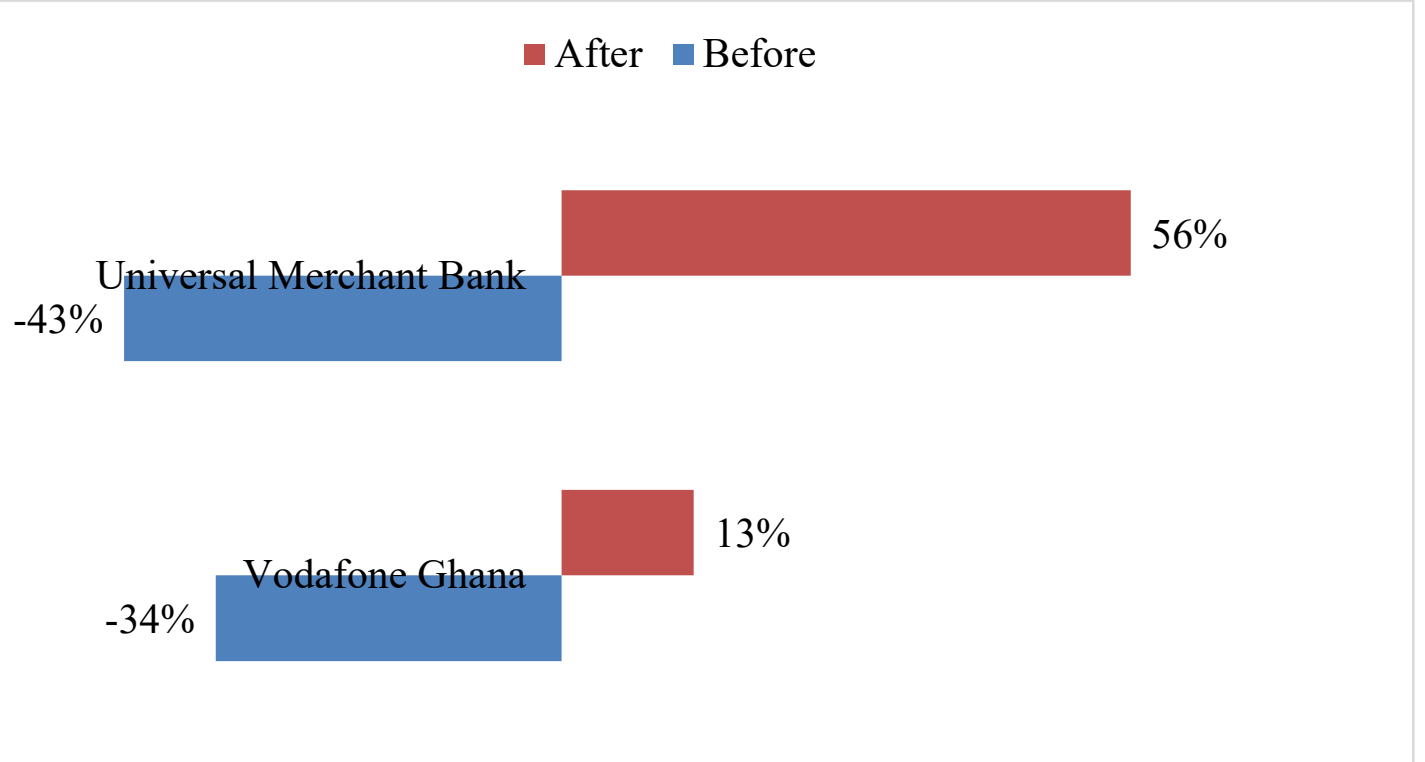

The current ratio was used to examine the two companies' abilities to pay back its liabilities (debt and accounts payable) with its assets in terms of cash, marketable securities, inventory and accounts receivable (Chapelle, 2010). As such, the current ratio was used to make a rough estimate of the two companies' financial health in the short-term. Vodafone Ghana's current ratio showed the firm's liquidity position to settle short term liabilities when due was $-34 \%$ before it was acquired and this figure improved to $13 \%$ after the company was purchased. Universal Merchant Bank posted $-43 \%$ before acquisition and $56 \%$ after it was privatized. This shows an encouraging performance by the two state enterprises. However, the increase in Universal Merchant Bank's current asset was mostly driven by asset held for sale which is very liquid compared to Vodafone Ghana asset mainly from cash and cash equivalent. The Universal Merchant Bank appears better placed to meet short term obligation when they fall due than Vodafone Ghana Limited.

c) Solvency or Gearing Analysis

Gearing focuses on the capital structure of the business, that means the proportion of finance provided by equity (shareholders), the gearing ratio is also a concern with long term financial stability of the business (Gorbunova, Vasyutkina, Kachkova, Demina, Baranova \& Novikova, 2015). Vodafone Ghana's gearing ratio before and after the privatization were $106 \%$ and $56 \%$ respectively with Universal Merchant Bank recording $140 \%$ before the acquisition but had a record of $68 \%$ after it was acquired. The higher increment of about $120 \%$ in long term debt after the privatization resulted from higher issuance of commercial papers and other long term debt capital purposely to finance the acquisition. The higher debt may also be a strategy to diversify the finance source and optimize their long debt mix and reduce working capital. This strategy appears to have worked with a gearing ratio of $167 \%$ is lower than that of Vodafone Ghana, though it's still higher, it may be acceptable in the industry in which the company operates.

Figure 5: Debt to Equity ratio

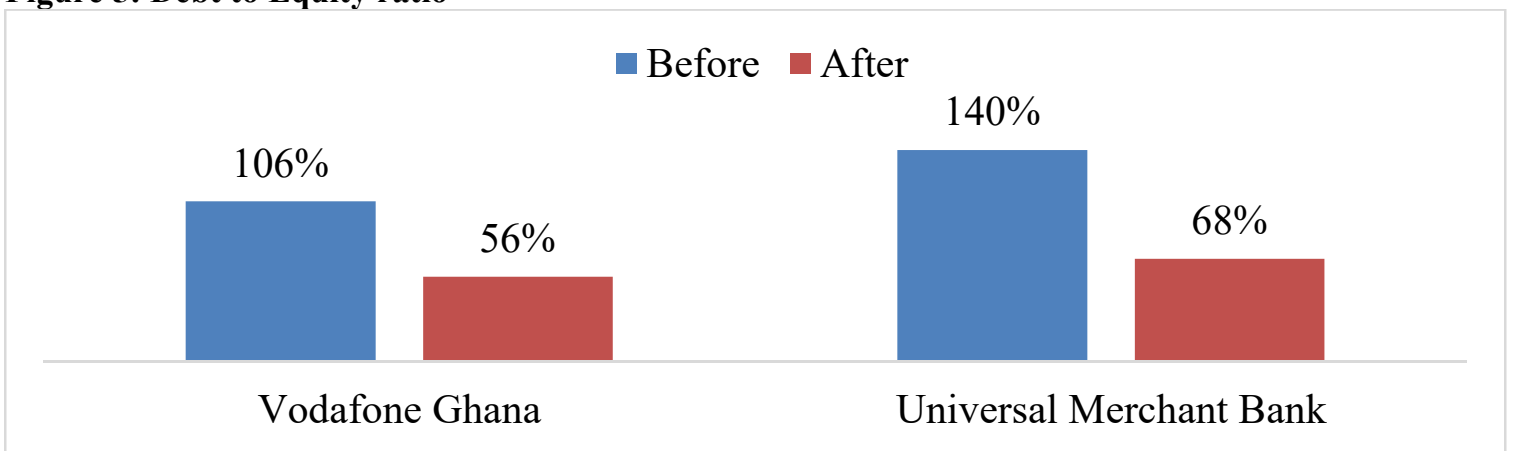

d) Efficiency Analysis

The efficiency analysis focuses on the following using the income and the expenses of the two companies. In assessing the efficiency of a company using cost to revenue ratio, a metric below $100 \%$ is ideal and vice versa. 
From Figure 6, Vodafone Ghana had cost to revenue ratio of $124 \%$ before it was acquired, and $29 \%$ after the company was acquired. Universal Merchant Bank recordred 284\% before acquisition and 65\% afterwards. Operating cost increment was fuelled by merger-related cost and charges from privatization which reduced the revenue of the two companies. To remain competitive the two companies should strive to cut down on their operating expenses by effective cost management methods and improve their revenue generating strategies by capitalising on their newly acquired brands and various synergies.

Figure 6: Cost to revenue

Universal Merchant Bank

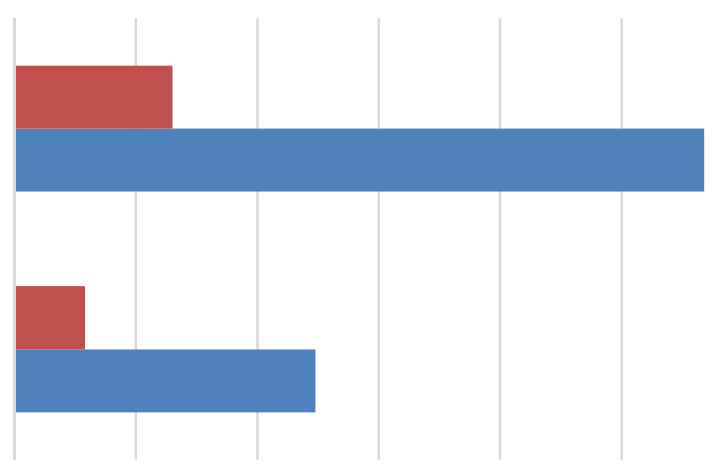

After

Vodafone Ghana

$\begin{array}{lllllllllll}0 \% & 50 \% & 100 \% & 150 \% & 200 \% & 250 \% & 300 \%\end{array}$

e) Investor ratio analysis

Earnings per share (EPS) are generally considered to be the most important variable in determining the worth of shares to shareholders (Wang \& Yung, 2011). Vodafone Ghana's EPS increased from $-\$ 1.04$ to $\$ 2.43$ after the privatization whilst Merchant Bank Limited recorded $-\$ 3.11$ before acquisition, and $\$ 1.67$ after the privatization respectively. The increase in the EPS of the two companies could be attributed to reduction in costs of operations which improved the earnings standings of the companies.

Figure 7: Earnings per share

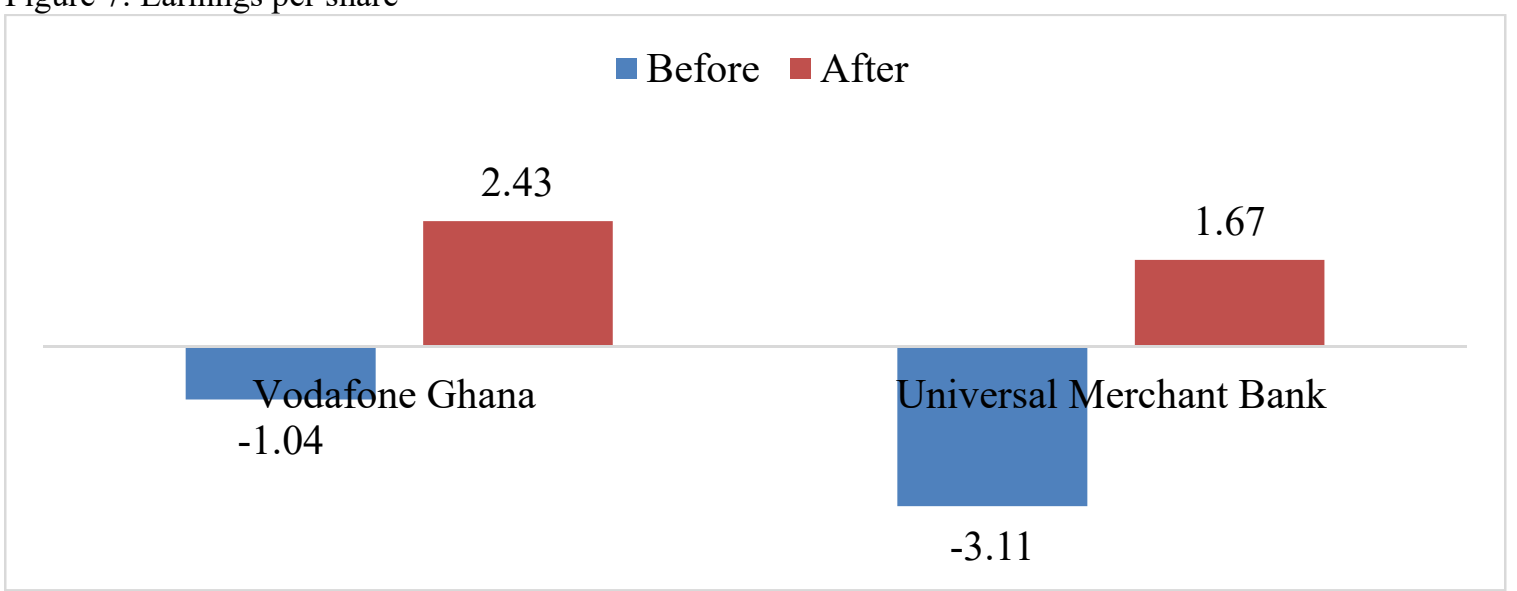

\section{Conclusion, Limitations and Recommendations \\ 5.1 Conclusion}

Bureaucratic systems coupled with weak internal control, corruption, mismanagement of funds among other factors influence governments to sell the state owned-enterprises. A state-monopolized function is prone to corruption; decisions are made primarily for political reasons, personal gain of the decision-maker rather than economic ones. Corruption (or principal-agent issues) in a state-run corporation affects the ongoing asset stream and company performance, whereas any corruption that may occur during the privatization process is a one-time event and does not affect ongoing cash flow or performance of the company. In order to wean their hands off from the affairs of the state enterprises, they offload their shares in these firms and give it to the private investors to manage them. In this study, factors such as political interferences, corruption, operational losses, weak internal controls and employees' poor attitude to work are the factors that influence the privatization of state enterprises in Ghana. This study also investigated the effects of privatization on the performance of two privatized state enterprises in Ghana by comparing pre- and post-privatization performance. The indicators used are profitability, operating efficiency, gearing, investment, and liquidity as well as the non-financial performance indicators. The results showed that on the average there are significant improvements in the performance of state enterprises after 
privatization.

\subsection{Limitations and Recommendations}

In this study, the researchers could not determine all the factors that leads to the privatization especially external influence from the international economic superpowers. The sample size of 278 respondents may not be representative enough to determine the factors that influence divestiture of state enterprises. Also, the financial ratios adopted to assess the performance of companies may not be statistically rigorous to test this phenomenon. There should be more studies on this subject employing more rigorous quantitative research methods and large sample size in future. At the corporate level, it is recommended that the state enterprises must revamp their internal structures and train their employees with the required skills to help them increase the productivity of the firms.

\section{References}

Abbas, M. and Raja, U., 2015. Impact of psychological capital on innovative performance and job stress. Canadian Journal of Administrative Sciences/Revue Canadienne des Sciences de l'Administration, 32(2), pp.128-138.

Adeyemo, D.O. and Salami, A.O., 2008. A review of privatization and public enterprises reform in Nigeria. Contemporary Management Research, 4(4).

Amoako, G.K. and Goh, M.K., 2015. Corporate Governance Practices of State-Owned Enterprises in Ghana: An Analysis. IUP Journal of Corporate Governance, 14(2), p.44.

Appiah-Kubi, K., 2001. State-owned enterprises and privatisation in Ghana. The Journal of Modern African Studies, 39(2), pp.197-229.

Arocena, P. and Oliveros, D., 2012. The efficiency of state-owned and privatized firms: Does ownership make a difference?. International Journal of Production Economics, 140(1), pp.457-465.

Bauer, H., 2015. The City of Potsdam: Between Privatization and Remunicipalization-Local Experiences and General Aspects on the Road to Publicization. European Public Law, 21(4), pp.723-746.

Bonin, J.P., Hasan, I. and Wachtel, P., 2005. Privatization matters: Bank efficiency in transition countries. Journal of Banking \& Finance, 29(8-9), pp.2155-2178.

Chapelle, K., 2010. Non-profit and for-profit entrepreneurship: a trade-off under liquidity constraint. International Entrepreneurship and Management Journal, 6(1), pp.55-80.

Chen, T.L., 2017. Privatization and efficiency: a mixed oligopoly approach. Journal of Economics, 120(3), pp.251268.

Conteh, C. and Ohemeng, F. L., 2009. The politics of decision making in developing countries: A comparative analysis of privatization decisions in Botswana and Ghana. Public management review, 11(1), pp.57-77.

Creswell, J.W. and Clark, V.L.P., 2017. Designing and conducting mixed methods research. Sage publications.

Edwards, J. B., 2016. Modern Gross Profit Analysis. Journal of Corporate Accounting \& Finance, 27(4), pp.4555.

Ginsburg, N., 2005. The privatization of council housing. Critical Social Policy, 25(1), pp.115-135.

Gogo, K., 2011. The impacts of the World Bank and IMF structural adjustment programmes on Africa: The case study of Cote D'Ivoire, Senegal, Uganda, and Zimbabwe. Sacha Journal of Policy and Strategic Studies, 1(2), pp.110-130.

Gorbunova, I. V., Vasyutkina, L. V., Kachkova, O. E., Demina, I. D., Baranova, E. N. and Novikova, D. M., 2015. State enterprises' financial stability coefficients. Review of European Studies, 7(9), pp.18.

Hanschen, P. W. and Erspamer, G. P., 2004. A Public Utility's Obligation to Serve: Saber or Double-Edged Sword?. The Electricity Journal, 17(10), pp.32-49.

Harris, K., 2013. The rise of the subcontractor state: politics of pseudo-privatization in the Islamic Republic of Iran. International Journal of Middle East Studies, 45(1), pp.45-70.

Hayllar, M. R. and Wettenhall, R., 2013. As public goes private, social emerges: The rise of social enterprise. Public Organization Review, 13(2), pp.207-217.

Kerlin, J.A., 2012. Defining social enterprise across different contexts: A conceptual framework based on institutional factors. In Social enterprises (pp. 91-117). Palgrave Macmillan, London.

Konadu-Agyemang, K. ed., 2018. IMF and World Bank sponsored structural adjustment programs in Africa: Ghana's experience, 1983-1999. Routledge.

Mains, D., 2012. Blackouts and progress: privatization, infrastructure, and a developmentalist state in Jimma, Ethiopia. Cultural Anthropology, 27(1), pp.3-27.

McCusker, K. and Gunaydin, S., 2015. Research using qualitative, quantitative or mixed methods and choice based on the research. Perfusion, 30(7), pp.537-542.

Megginson, W. L., 2017. Privatization, state capitalism, and state ownership of business in the 21 st century. Foundations and Trends in Finance, 11(1-2), pp.1-153.

Millward, R., 2013. The nature of state enterprise in Britain. In Reappraising State-Owned Enterprise (pp. 25-44). Routledge. 
Mutugi, J. M. and Ngugi, P. K., 2013. Effects Of Privatization On Performance Of Privatized Public Enterprises Listed In The Nairobi Security Exchange In Kenya: A Survey Of Privatized Firms In The Nairobi Security Exchange. International Journal of Innovative Research and Development, 2(8).

Nolan, P. and Xiaoqiang, W., 1999. Beyond privatization: Institutional innovation and growth in China's large state-owned enterprises. World Development, 27(1), pp.169-200.

Nwoye, M. I., 2011. Privatization of public Enterprises in Nigeria: The views and counterviews. Journal for Political theory and research on Globalization, Development and Gender Issues, 2(4), pp.234-251.

Obiwuru, T. C., Okwu, A. T., Akpa, V. O. and Nwankwere, I. A., 2011. Effects of leadership style on organizational performance: A survey of selected small scale enterprises in Ikosi-Ketu council development area of Lagos State, Nigeria. Australian journal of business and management research, 1(7), pp.100.

Oji, R. O., Nwachukwu, E. C. and Innocent, E. O., 2014. Privatisation of Public Enterprises in Nigeria: A Thematic Exposition. Singaporean Journal of Business, Economics and Management Studies, 51(1515), pp.1-16.

Omran, M., 2007. Privatization, state ownership, and bank performance in Egypt. World Development, 35(4), pp.714-733.

Onsomu, Z. N., Kaijage, E., Aduda, J. and Iraya, C., 2017. Risk Tolerance, Demographics and Portfolio Performance. Journal of Business and Economic Policy, 4(3), pp. 69-74.

Oppong, N. Y., 2013. The good and the bad of structural adjustment programme in Africa: Evidence from Ghanaian gold mining industry. International Journal of Business and Behavioral Science, 3(10), pp.27-41.

Raco, M., 2016. State-led privatisation and the demise of the democratic state: Welfare reform and localism in an era of regulatory capitalism. Routledge.

Starr, P., 1988. The meaning of privatization. Yale Law \& Policy Review, 6(1), pp.6-41.

Tian, L., and Estrin, S., 2008. Retained state shareholding in Chinese PLCs: does government ownership always reduce corporate value?. Journal of Comparative Economics, 36(1), pp.74-89.

Tsamenyi, M., Onumah, J. and Tetteh-Kumah, E., 2010. Post-privatization performance and organizational changes: Case studies from Ghana. Critical Perspectives on Accounting, 21(5), pp.428-442.

Wang, L. and Yung, K., 2011. Do state enterprises manage earnings more than privately owned firms? The case of China. Journal of Business Finance \& Accounting, 38(7-8), 794-812.

Weiss, L., 2014. America Inc.?: innovation and enterprise in the national security state. Cornell University Press.

Zeng, J., 2013. State-led privatization in China: The politics of economic reform. Routledge.

Zhou, K. Z., Gao, G. Y. and Zhao, H., 2017. State ownership and firm innovation in China: An integrated view of institutional and efficiency logics. Administrative Science Quarterly, 62(2), pp.375-404. 